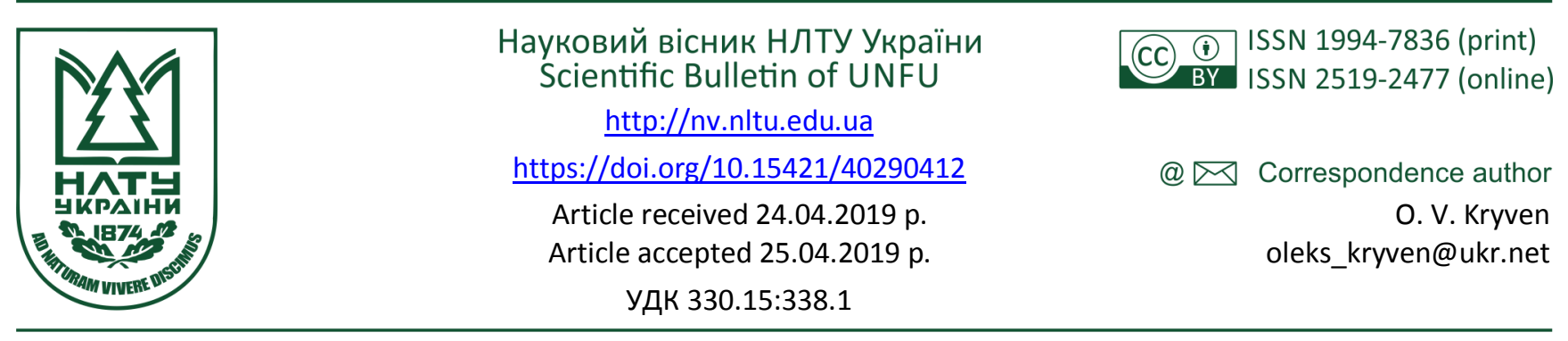

О. В. Кривень, І. Б. Назаркевич

Львівський національний університет ім. Івана Франка, м. Львів, Украӥна

\title{
РЕКРЕАЦІЙНО-ТУРИСТИЧНІ КЛАСТЕРИ ЯК ЕФЕКТИВНИЙ ІНСТРУМЕНТ РЕАЛІЗАЦІЇ ДЕРЖАВНОЇ ПОЛІТИКИ У РЕКРЕАЦІЙНІЙ СФЕРІ
}

Визначено, що пріоритетність рекреаційної сфери в Україні для залучення інвестицій та створення нових робочих місць зумовлює потребу в реалізації стратегічно орієнтованої державної політики, спрямованої на вирішення системних проблем у цій сфері. Вивчено позитивний зарубіжний досвід країн Європи, ПАР, Туреччини у створенні ефективних рекреаційно-туристичних кластерів, функціонування яких забезпечило розбудову забезпечувальної інфраструктури, покращення якості надання рекреаційно-туристичних послуг, підвищення конкурентоспроможності рекреаційно-туристичної сфери загалом. Узагальнено досвід України у створенні рекреаційно-туристичних комплексів, виявлено причини їхньої низької ефективності. Сформовано пропозиції щодо їх усунення шляхом використання механізму державно-приватного партнерства, перевагами застосування якого є істотна економія державних фінансів, залучення додаткових інвестиційних ресурсів, відновлення та модернізація інфраструктури, нова якість надання рекреаційно-туристичних послуг. Визначено, що перспективним для України є застосування кластерного підходу до розвитку рекреації і туризму в об'єднаних територіальних громадах, а також створення транскордонних рекреаційно-туристичних кластерів передусім в єврорегіонах "Буг", "Карпатський", "Нижній Дунай".

Ключові слова: рекреаційні ресурси; рекреаційно-туристична сфера; національна економіка; інвестиції; рекреаційно-туристичний кластер.

Вступ. Україна посідає одне $з$ провідних місць в Свропі за рівнем забезпеченості цінними природними та історико-культурними рекреаційними ресурсами, які здатні генерувати значний інтерес не тільки у вітчизняних, але й в іноземних рекреантів. Однак вона істотно програє в конкурентній боротьбі, відстаючи від провідних держав світу за рівнем розвитку рекреаційно-туристичної інфраструктури та якості рекреаційно-туристичних послуг, використовуючи тільки третину потенціалу, яким володіє. Підтвердженням цьому є, зокрема, прямий внесок подорожей і туризму (найбільш прибуткової складової рекреаційно-туристичної сфери) до ВВП України в 2018 р. у розмірі 5,4 \% (Ukraine, 2019). Для раціонального й ефективного використання рекреаційних ресурсів потрібно сформувати рекреаційно-туристичний простір шляхом створення та забезпечення функціонування зон розвитку курортів та туризму, розробити, впровадити та запропонувати споживачеві конкурентоспроможний національний рекреаційно-туристичний продукт (Stratehiia, 2017). 3 огляду на це виникає об'єктивна потребу в ефективніших діях державного менеджменту в контексті позиціонування національного продукту на ринку рекреаційно-туристичних послуг, сприяння залученню інвестицій у цю галузь, розбудову їі інфраструктури тощо.

Теоретичну та методологічну основу дослідження склали праці вітчизняних і зарубіжних вчених, зокрема Н. Андрусяк (Andrusiak, 2014), С. Ачкасової (Achkasova, Mamedova, \& Osadcha, 2018), А. Богославської (Воhoslavska, 2013), С. Волкова (Volkov, 2016), В. Горлачук і С. Січко (Horlachuk, \& Sichko, 2009), П. Оніпко, I. Петренко (Onipko, Petrenko, \& Skliar, 2015), Ю. Тимчишин-Чемерис (Tymchyshyn-Chemerys, 2015). Аналіз публікацій, що відображають досвід зарубіжних країн у використанні рекреаційно-туристичного кластеру (РТК) як інструменту державної політики у розвитку рекреаційної сфери, свідчить про його ефективність у подоланні низки проблем, зокрема недостатнього розвитку інфраструктури (транспортної, спортивної, готельної та розважальної), низького рівня рекреаційно-туристичних послуг та конкурентоспроможності цієї сфери загалом як на внутрішньому, так і на міжнародному ринках рекреаційно-туристичних послуг. Зазначені проблеми залишаються актуальними для вітчизняної рекреаційнотуристичної сфери. Тому пошук можливостей адаптації світового досвіду у створенні та розвитку рекреаційнотуристичних кластерів до вітчизняних реалій визначили вибір теми, мету і змістовну спрямованість цього дослідження.

Мета цієї наукової роботи - вивчити зарубіжний та вітчизняний досвід розвитку рекреаційно-туристичної сфери за допомогою створення кластерів, розроблення

Інформація про авторів:

Кривень Олександра Василівна, канд. екон. наук, доцент, кафедра економіки України. Email: oleks-kryven@ukr.net; https://orcid.org/0000-0001-7487-0760

Назаркевич Iгор Богданович, канд. екон. наук, доцент, кафедра економіки України. Email: nazarkevich@ukr.net; https://orcid.org/0000-0001-5856-531X

Цитування за ДСТУ: Кривень О. В., Назаркевич І. Б. Рекреаційно-туристичні кластери як ефективний інструмент реалізації державної політики у рекреаційній сфері. Науковий вісник НлТУ України. 2019, т. 29, № 4. С. 57-61.

Citation APA: Kryven, O. V., \& Nazarkevych, I. В. (2019). Recreation and tourism cluster as an effective tool of state politics realisation in recreational sphere. Scientific Bulletin of UNFU, 29(4), 57-61. https://doi.org/10.15421/40290412 
практичних рекомендацій щодо підвищення ефективності використання цього інструменту в Україні та визначити перспективні напрями створення нових РТК.

Викладення основного матеріалу дослідження. Сьогодні підхід до розвитку рекреаційно-туристичної сфери, заснований на кластерах, набуває чимраз більшого застосування у світовій практиці. Так, в Свропі кластерну модель організації рекреації і туризму впроваджують Норвегія, Франція, Італія. Наприклад, у Норвегії розвиваються кластери у сфері морського господарства. У Франції туристичний кластер "Ніцца" щороку відвідують декілька мільйонів туристів, що становить майже $1 \%$ від світового торговельного обігу в рекреаційно-туристичній сфері (Vikipediia, 2019). В Італії кластерна організація рекреаційно-туристичної сфери має високий рівень наукового обгрунтування. Наприклад, у деяких областях країни встановлено особливі умови, які $є$ підставою для їх створення: передумови для розвитку декількох видів туризму, значні рекреаційно-туристичні ресурси, значущість рекреаційно-туристичної зони тощо. Приклади РТК в Італії:

- туристична система "Тразименське озеро" (Умбрія);

- "Салінунтінські терми" (Сицилія);

• "Адріатичне море і берег", "Міста мистецтв, культури та бізнесу" (Емілія-Романія).

Схожі моделі на високому рівні функціонують у Греції, Шотландії, Бельгії, Іспанії, Ірландії. Для впровадження сучасних технологій у рекреаційно-туристичній сфері у 2007 р. засновано кластери в Польщі - "Сонце регіону" (м. Скаржисько-Кам'яна, Свєнтокшиське воєводство) та "Кришталь Європи" (м. Сувалки, Підляське воєводство).

Завдяки кластеру оздоровчого туризму, створеному у 2011 р., Естонія планує до 2020 р. стати однією 3 країнлідерів лікувальних курортів у світі (SPA-kurorty, 2019). Цей кластер об'єднав оздоровчі центри, санаторії, спа-курорти, а також туристичні та транспортні підприємства, наукові заклади. Співпраця його учасників спрямована на розвиток новітніх товарів і послуг оздоровчого туризму, зростання їх якості та популярності, а також послуг курортного лікування в Естонії і за кордоном.

Показовим є досвід ПАР, де органи державної влади і місцевого самоврядування проводять кластерну політику в рекреаційно-туристичній сфері за трьома головними напрямами:

1) сприяння інституційному розвиткові туристичних кластерів за допомогою залучення міжнародної консалтингової фірми і створення спеціалізованої Управлінської групи, визначення стратегічних напрямів розвитку кластерів і плану дій, налагодження інформаційної взаємодії між учасниками кластерів під час семінарів, консультацій, робочих зустрічей;

2) розвиток механізмів підтримки кластерних проектів, зокрема сприяння модернізації турпродуктів, їх просуванню на ринку, а також залученню інвестицій;

3) формування сприятливих умов розвитку туристичних кластерів шляхом підтримки професійної освіти і забезпечення безпеки.

На національному рівні процес формування кластера в ПАР трансформувався у створення добре продуманої структури, контроль за якою здійснювали представники бізнесу, держави i трудових колективів, що ввійшли до складу Управлінської групи (рис. 1). Для виконання консалтингових робіт було створено міжнародний консорціум (ТСС), який об'єднав кілька спеці- алізованих фірм з Південної Африки, Нової Зеландії та США і фінансувався 3 коштів державного бюджету. Мета проекту полягала в тому, щоб задати вектор розвитку рекреаційно-туристичній сфері як джерела надходжень і генератора робочих місць у країні на основі співпраці всіх зацікавлених сторін. Надалі вони повинні були самостійно розвивати розпочату справу.

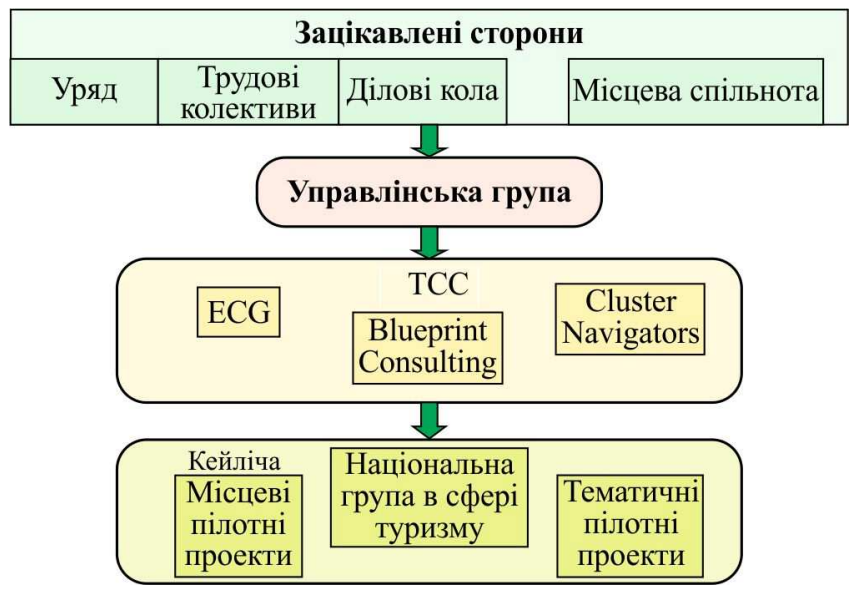

Рис. 1. Південно-Африканська модель створення рекреаційнотуристичного кластера (Volkov, 2016)

На локальному рівні, де найвідчутніші соціальноекономічні наслідки розвитку рекреаційно-туристичної сфери, ініціативи створення туристичних кластерів особливо важливі. Так, одна 3 найсильніших спільнот розвинулася в районі Кейліча (Khayelitsha), розташованого недалеко від Кейптауна. Цей район було вибрано як полігон для створення одного з чотирьох локальних РТК. Нерозвинена туристична сфера, конкуренція з боку інших туристичних районів країни, складна криміногенна ситуація - стартові умови для формування РТК в Кейлічі. Ініціювали його створення туристична адміністрація Капської провінції, яка на початках надала фінансову підтримку, і муніципалітет Тайге (Tyger). Poбота відбувалася у кілька етапів (рис. 2). Одним із перших кроків було навчання в Кейлічі Управлінської групи з представників різних зацікавлених організацій. Під час проведених нею семінарів, консультацій, робочих зустрічей 3 широким колом учасників, починаючи 3 місцевих жителів і працівників туристичної індустрії до політичних діячів і міністра туризму ПАР, було вироблено план дій за трьома стратегічними напрямами підготовка кадрів, маркетинг і забезпечення безпеки. Активну роль на цьому етапі взяли на себе члени міжнародного консорціуму ТСС, які надавали консалтингові послуги. Зазначимо, що ініціатива створення кластера походила знизу, всі зацікавлені сторони спільними зусиллями на місці виробляли стратегію розвитку за підтримки процесу прийняття рішень згори.

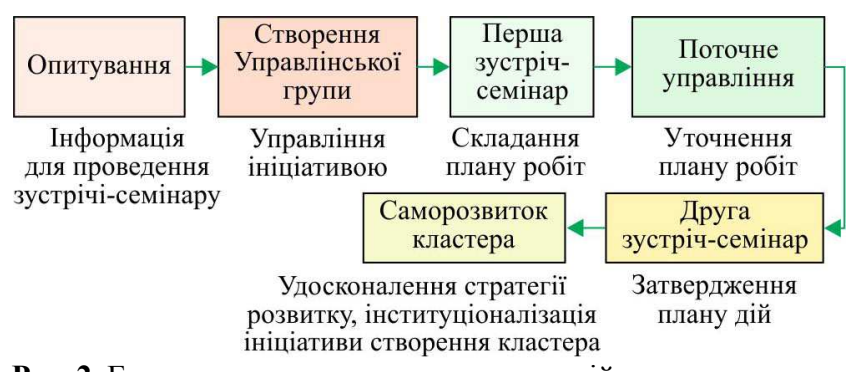

Рис. 2. Етапи створення локального рекреаційно-туристичного кластера в Кейлічі (Volkov, 2016) 
Не менш цікавим є досвід розвитку рекреаційно-туристичної сфери Туреччини, в якій на сьогодні існує сім функціональних туристичних кластерів: Султанахмет (Sultanahmet), Кушадаси (Kusadasi), Мармарис (Marmaris), Фетхіє (Fethiye), Таксім (Taksim), Каппадокія (Cappadoccia) та Анталія (Antalya). Всі туристичні кластери, крім Султанахмет і Каппадокія, сформовані на основі пляжного туризму та системи комплексного обслуговування "Все включено", яка стала маркетинговою складовою стратегії управління національним турпродуктом (Volkov, 2016, p. 8). Світовий досвід створення кластерів у різних галузях національної економіки ефективно впроваджується в Україні. Вона має певний досвід й у створенні РТК. Ними зокрема є:

- РТК "Південне туристичне кільце", туристичний маршрут по якому зорієнтований на системне ознайомлення туристів 3 найцікавішими сторінками історії малих міст півдня України. Цей кластер охоплює міста Одеської, Миколаївської та Херсонської областей (Bohoslavska, 2013; Horlachuk, \& Sichko, 2009);

- РТК "Гоголівські місця Полтавщини", діяльність якого від самого початку створення спрямована на організацію та популяризацію туристичних маршрутів й відповідної інфраструктури - готелів, закладів харчування, створення виставкових залів, торговельних об'єктів товарів народних промислів, реконструкцію пам'ятників М. Гоголя у населених пунктах області, музеїв та рекреаційних зон, створення рекламно-інформаційної продукції. Загалом на весь РТК "Гоголівські місця Полтавщини" було виділено 500 тис. гривень із державного бюджету та 300 тис. грн із місцевого бюджету (Onipko, Petrenko, \& Skliar, 2015, p. 14);

- рекреаційно-туристичний мегакластер "Діамантовий вінець України", створений у 2008 р. регіонами-переможцями Всеукраїнського конкурсу "Сім чудес України" для реалізації спільних комунікаційних, інформаційних, культурних, екскурсійних, туристичних та інших заходів, зокрема розвитку відповідної інфраструктури та логістики туристичного туру по об'єктах-переможцях (Andrusiak, 2014, с. 46). Ними стали: Кам'янець-Подільський Національний історико-архітектурний заповідник "Кам'янець" (Хмельницька обл.); Національний Києво-Печерський історико-культурний заповідник, Національний заповідник "Софія Київська"; Національний 3 дендрологічний парк "Софіївка" в Умані (Черкаська обл.); Національний заповідник "Херсонес Таврійський" у Севастополі; Національний заповідник "Хортиця" (Запорізька обл.); державний історико-архітектурний заповідник "Хотинська фортеця" на Буковині (Чернівецька область). Наступним етапом розвитку цього кластера $є$ розроблення та ліцензування екскурсійних турів (VIP, стандарт + , молодіжний тощо), реалізація пілотного проекту в Державному історико-архітектурному заповіднику "Хотинська фортеця";

- Подільсько-Буковинський туристичний кластер, трьома головними містами якого $є$ Кам'янець-Подільський, Чернівці та Хотин. Створення такого кластера базується на ідеї об'єднання різних об'єктів туристичної інфраструктури, які були розділені, в один конгломерат. Отже, туристи можуть розраховувати на комплекс послуг та цілісний рекреаційнотуристичний продукт. Туристам пропонують побачити унікальні історико-архітектурні пам'ятки міст, зокрема Кам'янець-Подільську та Хотинську фортеці, Чернівецький університет, старовинні храми, відвідати фестивалі та середньовічні бої, взяти участь в екстремальних розвагах, скуштувати місцеві страви та пізнати етнічні традиції.

Однак вітчизняні РТК розвиваються завдяки внутрішнім ресурсам місцевих громад та органів місцевого самоврядування, яких, безумовно, недостатньо. Адже не вирішеними питаннями залишаються: фінансування реставрації та підтримання у належному стані пам'яток національного значення, недосконале залізничне сполучення, бюрократичні перепони в оголошенні курортних зон для тих дестинацій, які мають для цього всі можливості; несприятливий інвестиційний клімат та ін.

Оскільки однією з основних перешкод розвитку рекреаційно-туристичної сфери в Україні є нерозвинена інфраструктура, то чи не єдиним інструментом реалізації інфраструктурних проектів у умовах децентралізації, за обмеженості бюджетних коштів, $є$ державно-приватне партнерство (ДПП). Перевагами від його застосування $є$ :

- значна економія публічних фінансів - до 80 \%.

- залучення додаткових інвестиційних коштів (кожен інвестований у туризм 1 дол. забезпечує 7 дол. інвестування в інших галузях);

- відновлення та модернізація інфраструктури;

- нова якість надання рекреаційно-туристичних послуг i, як наслідок, створення нових робочих місць, збільшення податкових надходжень та гармонійний розвиток регіонів (Instrument, 2019).

Понад це, зобов'язання сторін співпрацювати в рекреаційно-туристичній сфері для зміцнення ії конкурентоспроможності та розвитку як генератора економічного зростання і стимулювання економіки, зайнятості та валютних надходжень, закріплене у ст. 400 Угоди про асоціацію між Україною та Свропейським Союзом (Asotsiatsiia, 2019).

У нашій країні діє Закон України "Про державноприватне партнерство" (Zakon Ukrainy, 2010). Тому розвитку цієї співпраці у побудові, відновленні та реконструкції об'єктів інфраструктури (історико-культурних рекреаційних об'єктів також) сприятиме відповідне розуміння органів виконавчої влади, від якої бізнес очікує надання ділянок на пільгових умовах або безкоштовно, забезпечення підведення необхідних комунікацій, податкових стимулів (щонайменше до повернення інвестованих коштів), а також гарантій дотримання домовленостей у разі зміни влади.

Досвід створення РТК з використанням механізму державно-приватного партнерства має, зокрема, Російська Федерація. Так, створення тринадцяти РТК та підтримку проектів створення ще одинадцяти РТК за участю державних інвестицій в інженерну та забезпечувальну інфраструктуру охоплює федеральна цільова програма (ФЦП) "Розвиток внутрішнього і виїзного туризму в РФ на 2011-2018 pр." (Gosudarstvennaia Duma, 2010). Позабюджетні кошти при цьому спрямовуватимуться безпосередньо в туристичні об'єкти, готелі, спортивні споруди та оздоровчі комплекси. Отже, за основу реалізації регіональних проектів у ФЦП прийнято кластерний підхід, який неможливо реалізувати без механізмів державного та приватного партнерства.

Постановою Уряду РФ від 7.02.2018 р. внесено зміни у ФЦП, в ході яких вона набула сучасного вигляду, охопивши заходи зі створення 47 РТК. Загальний обсяг ii фінансування становив 120670,3 млн руб., зокрема кошти федерального бюджету - 26719,8 млн руб., кошти бюджетів суб'єктів РФ і місцевих бюджетів 8396,9 млн руб., позабюджетні джерела - 85553,6 млн руб. (Pravitelstvo RF, 2011). На виконання завдання ФЦП "Розвиток рекреаційно-туристичного комплексу Російської Федерації" закладено 117292,9 млн руб., або 97,2\% усіх коштів, 3 них капітальні інвестиції117066,7 млн руб., або 99,8 \% усіх коштів, виділених на 
фінансування заходів для виконання цього завдання. Як зазначалося, РТК $є$ важливим інструментом для розбудови інфраструктури рекреаційно-туристичної сфери. На виконання заходів ФЦП "Розвиток внутрішнього і виїзного туризму в РФ на 2011-2018 pp." із будівництва і модернізації туристичних об'єктів 3 тривалим терміном окупності, створення і реконструкцію комплексів забезпечувальної інфраструктури виділено 117066,7 млн руб., 3 них 20,9 \% - кошти федерального бюджету, $6,5 \%$ - кошти суб'єктів РФ і місцевих бюджетів, 72,6 \% - кошти з позабюджетних джерел.

Пріоритетними територіями для створення РТК визначено Далекосхідний федеральний округ, ПівнічноКавказький федеральний округ та Калінінградську обл. (таблиця).

Таблиця. Рекреаційно-туристичні кластери на пріоритетних територіях, зараховані у ФЦП "Розвиток внутрішнього і виїзного туризму в РФ на 2011-2018 рр."

\begin{tabular}{|c|c|c|c|c|c|}
\hline \multirow[b]{2}{*}{$\begin{array}{c}\text { № } \\
\text { 3/П }\end{array}$} & \multirow[b]{2}{*}{ Регіон } & \multirow[b]{2}{*}{ Рекреаційно-туристичний кластер } & \multirow{2}{*}{$\begin{array}{l}\text { Загальна } \\
\text { вартість, } \\
\text { млн руб. }\end{array}$} & \multicolumn{2}{|c|}{ Ефект } \\
\hline & & & & $\begin{array}{l}\text { додатк. робо- } \\
\text { чих місць, од. }\end{array}$ & $\begin{array}{l}\text { збільшення тур- } \\
\text { потоку, тис. ос. }\end{array}$ \\
\hline 1 & Республіка Саха (Якутія) & "Північна Мозаїка" & 1218,3 & 162 & 370 \\
\hline 2 & Амурська область & "Амур" & 3305,7 & $>300$ & 133,9 \\
\hline 3 & Хабаровський край & "Острів Великий Уссурійський Шантари" & 2776,9 & $>916$ & 123 \\
\hline 4 & Кабардино-Балкарська Республіка & "Зарагіж" & 2877,5 & $>320$ & 55 \\
\hline 5 & Ставропільський край & "Еко-курорт Кавмінводи" & 1573,5 & 650 & 32,7 \\
\hline 6 & Чеченська Республіка & "Кезеній-Ам" & 1026,6 & 228 & 65 \\
\hline 7 & Республіка Інгушетія & "Всесезонний туристичний центр Інгушетія" & 1176,7 & 520 & 29,2 \\
\hline 8 & Республіка Лагестан & "Золоті піски" & 500 & 60 & 7,5 \\
\hline 9 & Респуолика дагестан & "Золоті дюни" & 123,3 & 150 & 5 \\
\hline 10 & Карачаєво-Черкеська Республіка & "Еко-курорт Кавмінводи" & 3124,3 & 270 & 92,7 \\
\hline 11 & Калінінградська область & "Раушен" & 5462 & $>925$ & 134,4 \\
\hline
\end{tabular}

Примітка: складено на основі (Pravitelstvo RF, 2011, p. 131-137).

На основі державно-приватного партнерства реалізується найбільш масштабний і прогресивний проект створення туристичного кластера в Північно-Кавказькому федеральному окрузі, Краснодарському краї і Республіці Адигея, відповідно до концепції формування якого створено шість особливих економічних зон рекреаційно-туристичного типу. Цей проект передбачає будівництво до 2020 р. п'яти гірськолижних курортів із сучасною транспортною, інженерною і соціальною інфраструктурою в інтересах усіх суб'єктів Північного Кавказу зокрема для створення близько 160 тис. робочих місць (при повній реалізації потенціалу, за попередніми оцінками експертів, до 320 тис. робочих місць). Загальна площа курортів становитиме 4 тис. га, а бюджет проекту - 451,44 млрд руб., 3 них 272,0 млрд руб. - кошти інституційних інвесторів, 119,28 млрд руб. - приватні інвестиції і кредити банків. Обсяг державних інвестицій становитиме близько 60 млрд руб. (Volkov, 2016, p. 13).

На нашу думку, проаналізований вище досвід РФ у реалізації проектів щодо створення РТК з використанням механізму державно-приватного партнерства $\epsilon$ свідченням розуміння та зростаючого інтересу регіональної та федеральної влади до цього методу територіального управління як можливості вирішення низки соціально-економічних проблем завдяки розвитку рекреаційно-туристичної сфери.

Величезний потенціал для розвитку РТК в Україні, реалізація якого дасть змогу успішно конкурувати на міжнародному ринку рекреаційно-туристичних послуг, прихований у створенні транскордонних кластерів. Сьогодні наша країна задіяна у двох транскордонних РТК. Перший - транскордонний кластер сільського "зеленого" туризму в єврорегіоні "Дніпро", головним завданням якого $є$ пропаганда ідей активного розвитку сільського туризму як одного 3 напрямів сталого соціально-економічного розвитку сільських територій Гомельської та Чернігівської областей (Onipko, Petrenko, \& Skliar, 2015, p. 10). Цей кластер об'єднує понад 300 природних та історико-культурних рекреаційних об'єктів шести районів згаданих вище областей, а також 31 агросадибу, 5 фермерських господарств, 4 туристичних підприємства, туристсько-інформаційний центр, 8 районних сільських рад, 6 сільських загальноосвітніх шкіл, 12 сільських кооперативів, 2 громадських об'єднання, 9 підприємств малого бізнесу, 2 університети. Для туристів розроблено низку "зелених" маршрутів - пішохідних, велосипедних, кінних, зокрема маршрути вихідного дня, а також спеціальні пропозиції для байкерів і любителів екстрим-туризму.

Інший транскордонний РТК почав діяти у 2015 р. у географічних межах Львівської, Волинської, Закарпатської областей України і Підкарпатського та Люблінського воєводств Польщі (Onipko, Petrenko, \& Skliar, 2015 , p. 10). Передумовою його створення є потужний природно-ресурсний потенціал транскордонного регіону (національні парки, лікувальні мінеральні ресурси, оздоровчі заклади), наявність унікальних історикокультурних рекреаційних ресурсів (велика кількість пам'яток замково-палацової та релігійної культури), сприятливе географічне розташування на перетині міжнародних транзитних шляхів, розвинена мережа інституцій і організацій підтримки малого і середнього бізнесу в галузі рекреації і туризму, розвинена мережа закладів для підготовки кадрів у рекреаційно-туристичній сфері, наявність висококваліфікованих працівників у цій сфері та ін.

Висновки. Як свідчить світова та вітчизняна практика, РТК можуть бути важливим інструментом розвитку рекреаційно-туристичної сфери (напр., розроблення нових маршрутів, розбудови відповідної інфраструктури), підвищення іiі конкурентоспроможності. Тому питання розвитку РТК в Україні потребує подальшого вивчення із застосуванням комплексно-системного підходу, залучивши у цей процес правові, інституційні та фінансові інструменти. Перспективним, на нашу думку, $\epsilon$ застосування кластерного підходу до розвитку рекреації і туризму в об'єднаних територіальних громадах та створення транскордонних РТК в інших єврорегіонах, передусім таких, що поширюються на країни $\mathrm{CC}$ - 
"Буг" (Волинська обл. України, Брестська обл. Білорусі та Люблінське воєводство Польщі), "Карпатський" (Україна, Польща, Словаччина, Угорщина, Румунія), "Нижній Дунай" (Україна, Молдова, Румунія).

\section{Перелік використаних джерел}

Achkasova, S. A., Mamedova, E. R., \& Osadcha, S. S. (2018). Upravlinnia rozvytkom turystychnoho klastera za uchasti strakhovykh kompanii. Scientific Bulletin of Mykolaiv V. O. Sukhomlynskyi National University, 23, 144-148. [In Ukrainian].

Andrusiak, N. S. (2014). Rekreatsiino-turystychni klastery yak efektyvnyi instrument mizhrehionalnoi ta mizhnarodnoi spivpratsi. Geography and Tourism, 28, 39-47. [In Ukrainian].

Asotsiatsiia. (2019). Uhoda pro asotsiatsiiu mizh Ukrainoiu, z odniiei storony, ta Yevropeiskym Soiuzom, Yevropeiskym spivtovarystvom z atomnoi enerhii i yikhnimy derzhavamy-chlenamy, z inshoi storony: Mizhnarodnyi dokument vid 27 chervnia 2014 r. Retrieved from: http://zakon2.rada.gov.ua/laws/show/984_011. [In Ukrainian].

Bohoslavska, A. V. (2013). Rehionalnyi turystychnyi klaster - kliuchovyi priorytet rozvytku rekreatsiino-turystychnoi industrii Pivdennoho rehionu. Bulletin of agrarian of the Black Sea region, 4(1), 36-42. Retrieved from: http://nbuv.gov.ua/UJRN/vanp 2013 4(1) 7. [In Ukrainian].

Gosudarstvennaia Duma. (2010). Razvitie vnutrennogo i vezdnogo turizma v Rossiiskoi Federatcii (2011-2018): Federalnaia tcelevaia programma ot 19 iiulia 2010 g., № 1230-r. Retrieved from: https://www.russiatourism.ru/contents/deyatelnost/programmy-iproekty/federalnaya-tselevaya-programma-razvitie-vnutrennego-ivezdnogo-turizma-v-rossiyskoy-federatsii-2011-2018-gody-/. ] [In Russian].

Horlachuk, V. V., \& Sichko, S. M. (2009). Klasterna model rozvytku turyzmu. Economy and region, 2(21), 28-31. [In Ukrainian].

Instrument. (2019). Rozvytok turystychnoi industrii yak instrument ekonomichnoho rozvytku ta investytsiinoi pryvablyvosti Ukrainy:
Parlamentski slukhannia vid 6 kvitnia 2016 r. Verkhovna Rada Ukrainy. Retrieved from: http://www.rada.gov.ua. [In Ukrainian].

Onipko, T. V., Petrenko, I. M., \& Skliar, H. P. (Ed.). (2015). Turystychnyi klaster "Hoholivski mistsia Poltavshchyny". Modernizatsiia turyzmoznavstva: teoriia i praktyka partnerstva. Poltava, pp. 215-231. [In Ukrainian].

Pravitelstvo RF. (2011). O vnesenii izmenenii v Federalnuiu tcelevuiu programmu "Razvitie vnutrennego $i$ vezdnogo turizma $v$ Rossiiskoi Federatcii (2011-2018)": Postanovlenie Pravitelstva Rossiiskoi Federatcii ot 7 fevralia 2018 g., № 117. Retrieved from: http://fcp.economy.gov.ru/cgi-bin/cis/fcp.cgi/Fcp/ViewFcp/View/ 2013/361/?yover=2018. [In Russian].

SPA-kurorty. (2019). Estoniia planiruet $k 2020$ godu stat odnim iz luchshikh lechebnykh SPA-kurortov mira. Retrieved from: http:/vtallinn.blogspot.com/2011/11/2020.html. [In Russian].

Stratehiia. (2017). Stratehiia rozvytku turyzmu ta kurortiv na period do 2026 roku: Rozporiadzhennia Kabinetu Ministriv Ukrainy vid 16 bereznia 2017 r., № 168-r. Retrieved from: http://zakon.rada. gov.ua/laws/show/-168-2017-\%D1\%80. [In Ukrainian].

Tymchyshyn-Chemerys, Yu. V. (2015). Turystychnyi klaster - forma rozvytku ta uspikhu turystychnoi diialnosti rehionu. Bulletin of agrarian of the Black Sea region, 4, 44-57. [In Ukrainian].

Ukraine. (2019). Annual research: key highlights. World Travel\&Tourism Councial. Retrieved from: https://www.wttc.org/economicimpact/country-analysis/country-data/

Vikipediia. (2019). Turystychnyi klaster. Vikipediia vilna entsyklopediia. Retrieved from: https://uk.wikipedia.org/wiki/Turystych nyi klaster. [In Ukrainian].

Volkov, S. K. (2016). Zarubezhnyi i rossiiskii opit razvitiia turistskikh klasterov. (Ser. Economy. Computer Science). Scientific statements, 16(237), 39, 5-15. [In Russian].

Zakon Ukrainy. (2010). Pro derzhavno-pryvatne partnerstvo vid 01.07.2010 r., № 2404-VI/ Verkhovna Rada Ukrainy. Retrieved from: http://zakon3.rada.gov.ua/laws/show/2404-17. [In Ukrainian].

O. V. Kryven, I. B. Nazarkevych

Ivan Franko National University of Lviv, Lviv, Ukraine

\section{RECREATION AND TOURISM CLUSTER AS AN EFFECTIVE TOOL OF STATE POLITICS REALISATION IN RECREATIONAL SPHERE}

National recreation and tourism sphere can possess top positions in state economics as it has rich natural, historical and cultural resources and cultural identity although its further development is being hindered due to undeveloped transport, sport, hotel and entertainment infrastructure. These issues are easily figured out in foreign countries by means of recreation and tourism clusters formation. That is why the researching of foreign and native experience is actual as for the clusters formation, disadvantages, flaws and new possibilities identification for raising the effectiveness of this tool in Ukraine. In the research the next methods are applied: comparative, generalization, abstract and logic analysis. The authors analyse the positive experience of European countries, SAR, and Turkey in the providing of development and competitiveness of recreation and tourism sphere due to formation of such clusters. Ukraine's experience is also analysed considering such clusters functioning as "South Tourism Circle", "Gogol Places of Poltava", "Diamond Wreath of Ukraine ", and Podillya and Bukovyna tourism clusters. The development of Ukrainian recreation and tourism clusters is identified to be restrained because of funding lack for national historical monuments restoration and maintenance in appropriate condition, flawed train communication, bureaucratic obstacles for announcement of resort zones for the destinations which have all the possibilities, and inappropriate investments climate. It is revealed that the implementation of infrastructural projects within recreation and tourism clusters in decentralization conditions and with limited budgets will be enhanced by a state and private partnership tool. Appropriate experience of Russian Federation is analysed as an example. It is found that it is perspective to apply cluster approach in Ukraine to the development of recreation and tourism in joined local societies which are interested in these tools. Another possibility for effective recreation and tourism clusters development is creation of such transborder clusters as "Bug", "Carpathian", "Nyzhniy Dunay" in Euro-region including EU countries.

Keywords: recreational resources; recreation and tourism sphere; national economics; infrastructure; investments; recreation and tourism cluster. 